Dept. Theriogenology

Fac. Vet. Med., Assiut University.

\title{
MORPHOMETRIC AND IMMUNOHISTOCHEMICAL VARIATIONS IN THE CAMEL (CAMELUS DROMEDARIUS) TESTIS IN RELATION TO SOME ENDOCRINOLOGICAL ASPECTS DURING DIFFERENT SEASONS OF THE YEAR
}

(With 2 Tables and 3 Figures)

By

\section{D.R.I. DERAR; H.A. HUSSEIN and A.M. SALEH*}

*Dept. of Anatomy and Histology, Fac. Vet. Med., Assiut University

(Received at 16/12/2004)

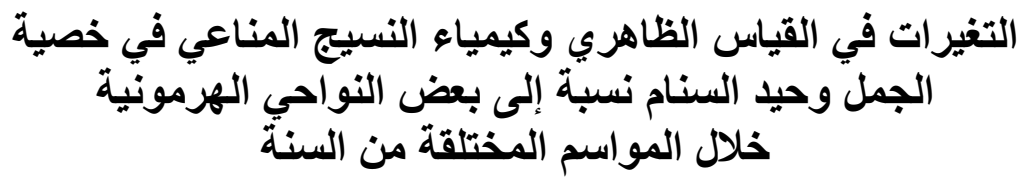

ضرار رفعت ضرار ، حسن عبل الصبور حسين ، عبل المهيمن مصطفى صالح

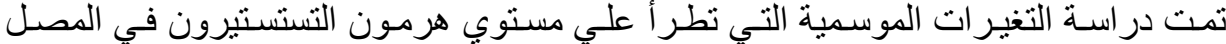

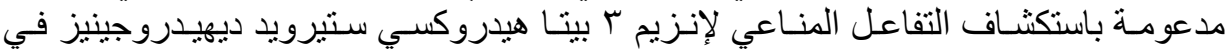

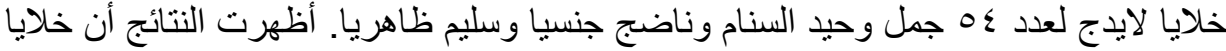

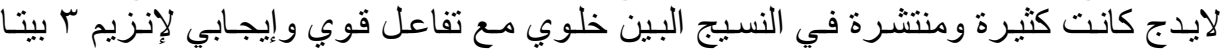

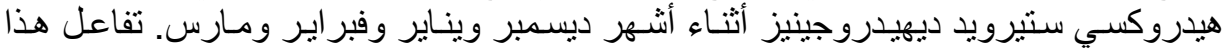

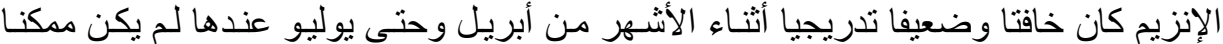

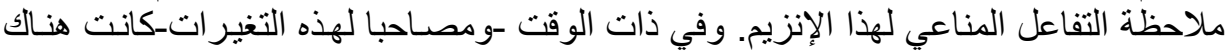

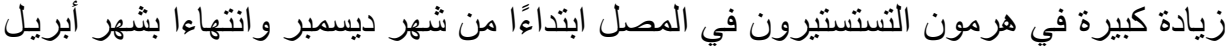

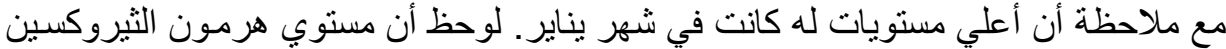

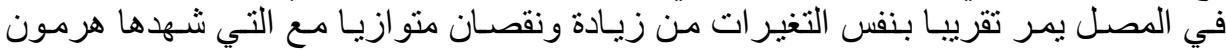

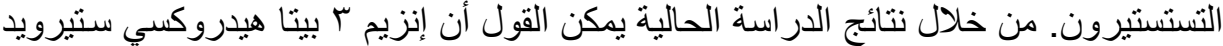

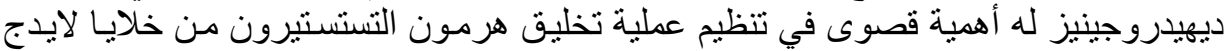

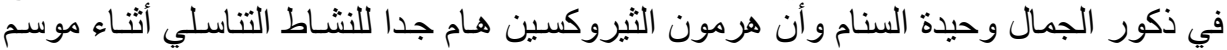
التزاوج في ذكور الجمال وحيدة السنام ويمر بنفس التغيرات التير هين يمر بها هرمون الذكورة.

\section{SUMMARY}

Seasonal variation in serum testosterone, thyroxin and the testicular morphology were studied in 54 sexually mature and apparently healthy one-humped camels during the different seasons of the year. The 
testosterone and thyroxin serum levels were measured and $3 \beta$ hydroxysteroid dehydrogenase activity of Leydig cells was assessed immunohistochemically to aid in the interpretation of results. The activity of $3 \beta$-HSD was high during cold months and severely depressed to the minimum activity in hot months. Concomitantly, serum testosterone and thyroxin levels increased during the winter and early spring and decreased thereafter. Their levels reached the peak during the months of January till April. These results suggested that $3 \beta-H S D$ is a key enzyme in the regulation of the testosterone production in Leydig cells of the male dromedary. Thyroxin is a crucial hormone for the male reproductive activity during the breeding season in the dromedary and fluctuated in the same pattern as serum male androgen.

Key words: Camel, immunohistochemical, testis, thyroxin 3 $\beta$-HSD.

\section{INTRODUCTION}

Seasonal changes in the camels could be clarified through studying morphology of the testis, histochemical observation of the testes and studies on the male accessory sex glands (Abdel-Raouf and Owaida 1974, Abdel-Raouf et al. 1975). It has been found that in seasonal breeders the mating and nonmating seasons are clearly related to different levels of testosterone in the plasma and testes (Racey, 1978). Clear correlation between testicular steroidogenesis and reproduction is well exemplified in the dromedary that is not a typical seasonal breeder. The rate of synthesis of testosterone is high during the mating season and low during the nonmating season (Friedlander et al. 1984).

Seasonality in the male is evidenced by changes in sexual behaviour, morphology and function of the genital organs, as well as changes in endocrinological profiles. In seasonal breeders, the effect of photoperiod is undeniable. In this regard, Vaughan et al. (1982) explained that chronic exposure of female Syrian hamsters (long day breeders) for 9 weeks to a short photoperiod (10L:14D) depressed the pituitary-thyroid axis as indicated by a drop in circulating titers of thyroid stimulating hormone (TSH), thyroxin (T4), triiodothyronine (T3) and the free thyroxin index (FT4) compared to animals maintained under long photoperiodic conditions. $90 \%$ of iodine circulating in the animal's blood is in the form of $\mathrm{T}_{4}$ (Wilson, 1975). Lack of iodine prevents production of both $\mathrm{T}_{4}$ and $\mathrm{T}_{3}$ (Guyton, 1991). The enzyme

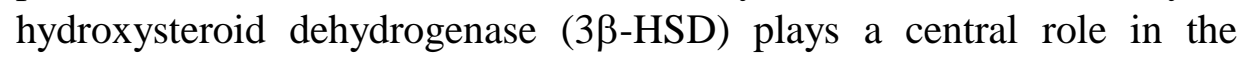


biosynthesis of steroid hormones, including androgens (Conley and Bird 1997; Penning 1997). 3 $\beta$-HSD is present in the testis, ovary and placenta, adrenal gland as well as in a large number of peripheral intracrine tissues, including the prostate, breast, liver and skin (Ferre et al. 1975; Lacoste et al.1990). It catalyzes the final step in progesterone biosynthesis in the ovary and is required for testosterone production in the testis. Different 3 $\beta$-HSD isoforms have been cloned from various tissues from humans, rats and mice (Simard et al. 1993 and 1995 and Penning 1997).

The purpose of the present work was to investigate the correlation between seasonal changes in serum testosterone and thyroxin hormones from one side and the $3 \beta$-HSD activity and testicular morphology on the other side.

\section{MATERIALS and METHODS}

The testes of 48 sexually mature (5-12 years old) and apparently healthy one-humped camels were obtained from Bany-Ady (Assiut governorate) and Cairo slaughterhouses. The materials were collected at regular monthly intervals over a period of twelve months. Within one hour after slaughter, the scrotum was incised, the testes were removed and the volume was taken. For the histological morphometric study, the testes were cut in slices and small cubes from the testicular parenchyma were taken and fixed in neutral buffer formalin contained $1 \%$ glutaraldehyde. Then, processed for paraffin embedding, and sections of $5 \mu \mathrm{m}$ thick were cut and stained with $\mathrm{H} \& \mathrm{E}$.

Morphometric studies: The weight of testes was taken and their volume was measured by water displacement method (Willett and Ohms, 1957 and Scherle, 1970). The testicular parenchymal volume was calculated by subtraction of $11 \%$ from the testicular volume. These $11 \%$ represent the volume of tunica albuginea and rete testis (Wrobel 1990). Different histological morphometric values were carried out on H\&E stained sections using Leica Q 500 MC Image analyzer.

\section{3 $\beta$-Hydroxysteroid dehydrogenase (3 $\beta$-HSD):}

Fixation: Immediately after slaughter, the testes were removed from their envelopes and samples of suitable size (about $1.0 \times 0.5 \times 0.5 \mathrm{~cm}$ ) were taken from different regions testis every month. Immersion fixation was carried out in two steps. Fixative I (30 min) contained $4 \%$ paraformaldehyde; $15 \% \mathrm{v} / \mathrm{v}$ saturated picric acid; $0.1 \%$ glutaraldehyde in $0.1 \mathrm{M}$ phosphate buffer, $\mathrm{pH}$ 7.4. Fixative II (several hours) had the same composition as fixative I but without glutaraldehyde. Following fixation, 
the blocks were washed in $0.1 \mathrm{M}$ phosphate buffer, transferred into a graded series $(10 \%, 20 \%, 30 \%)$ of saccharose-containing rinsing buffer and shipped by air to Regensburg. Here, the samples were immersed in Tissue Tek OCT compound (Miles, Elkhardt, Ind., USA) and snapfrozen in liquid nitrogen. Cryostat sections $(12 \mu \mathrm{m}$ thick $)$ were mounted on gelatin/chrome alum-coated slides and air-dried for 2 - 3 min before further treatment.

Immunohistochemistry: All subsequent steps were carried out in a moist chamber on slides with sections surrounded by water-repellent PAP-PEN (SCI Science Services, München, Germany). Sections were rinsed ( $3 \times 10 \mathrm{~min}$ ) in TBS: $0.1 \mathrm{M}$ TRIS (pH 7.4); $0.8 \% \mathrm{NaCl} ; 0.0015$ $\%$ Triton X-100 between the consecutive steps of the test. (1) Nonspecific bindings were blocked by preincubation $(60 \mathrm{~min})$ with blocking buffer containing $0.1 \mathrm{M}$ TRIS ( $\mathrm{pH} 7.4$ ); $0.15 \%$ Thimerosal; $0.8 \%$ Triton X-100; $0.8 \% \mathrm{NaCl} ; 20 \%$ normal goat serum; $20 \%$ fetal calf serum. (2) Incubation (overnight) with primary antiserum (rabbit antimouse adrenal/gonadal $3 \beta$-HSD) at a dilution in blocking buffer of 1:512 overnight at $4^{\circ} \mathrm{C}$. (3) Incubation $(60 \mathrm{~min})$ in secondary antibody/biotinylated in blocking buffer. (4) Blocking of endogeneous peroxidase with phenylhydrazine. (5)Incubation $(60 \mathrm{~min})$ in $\mathrm{AB}$ complex (ABC). (6) Developing with $0.5 \mathrm{mg} / \mathrm{ml} \mathrm{DAB}$; in $0.1 \mathrm{M}$ TRIS (pH 7.4) containing $0.002 \% \mathrm{CoCl}_{2} \cdot 6 \mathrm{H}_{2} \mathrm{O} ; 0.4 \% \mathrm{NiCl}_{2} \cdot 6 \mathrm{H}_{2} \mathrm{O}$ and $0.012 \% \mathrm{H}_{2} \mathrm{O}_{2}$. (7) Rinsing once in TBS, dehydration, mounting in DPX. Controls for immunohistochemistry: Controls included: (a) Omission of the primary antiserum. (b) Substitution of primary antiserum by nonimmune serum 1: 500 in blocking buffer. (c) Blocking of the primary antibody by preincubation with the matching antigen in excess. No immunostaining was obtained after any of these control procedures (a-c). Blood sampling and hormonal assay: Samples were collected by Venipuncture at a monthly interval from six mature male camels housed in the veterinary teaching clinic, Assiut Univ. and its neighborhood. Samples were kept at $4^{\circ} \mathrm{C}$ for 30 minutes and the serum was obtained after centrifugation at $3000 \mathrm{rpm}$ for 20 minutes and stored at $-20^{\circ} \mathrm{C}$ till assay. Serum testosterone and Thyroxin were determined using ELISA kit (Biosource, Europe, S.A., Code, 40 17000). Inter- and intra-assay coefficients were $6.2,6.4 \%$ for testosterone and 11.4 and $11.7 \%$ for Thyroxin, respectively.

Statistical analysis: Statistical analysis of the collected data was carried out according to procedures of completely random design, SAS (1995).

\section{RESULTS}


The weight, volume densities (mean $\pm \mathrm{SE}$ ) of testes and testicular parenchyma throughout the year are shown in (Table 1, Fig 1A). There was one fold difference between the highest and lowest mean testicular volume during different reproductive cycle. The testicular weight and volume showed similar peak during the breeding phases. The testes began to increase in weight and volume from quiescence (September) and attained a peak during breeding season (December, January and February). Then, testes declined in volume and weight in March and April to reach the lowest values in July.

The epithelial height and diameter of seminiferous tubules (table 1, Fig 1B) displays statistically significant annual changes. The tubular diameter showed significant increase in February and March and lowest values were recorded in July. The epithelial height showed significantly higher values during the breeding season in December and January. The Leydig cells started to increase in number in September to reach the maximum number in December and showed significant seasonal variations (table 1, Fig 1B).

Table 1: seasonal and monthly variation in testicular volume, diameter of seminiferous tubules and epithelial height of seminiferous tubules in the male dromedary $(n=48)$.

\begin{tabular}{|c|c|c|c|c|c|c|c|}
\hline Mon. & $\begin{array}{c}\text { Day } \\
\text { length } \\
\text { (hrs) }\end{array}$ & $\begin{array}{l}\text { Testicular } \\
\text { weight }(\mathrm{g})\end{array}$ & $\begin{array}{c}\text { Testicular } \\
\text { Volume } \\
\text { (c.c.) }\end{array}$ & $\begin{array}{l}\text { Parenchyma } \\
\text { volume of } \\
\text { (c.c.) }\end{array}$ & $\begin{array}{l}\text { Leydig cells } \\
\text { number/Crosse } \\
\text { section } 250 \mathrm{X}\end{array}$ & $\begin{array}{l}\text { Diameter of } \\
\text { seminiferous } \\
\text { tubules }(\mu \mathrm{m})\end{array}$ & $\begin{array}{r}\text { Epithelial } \\
\text { height }(\mu \mathrm{m})\end{array}$ \\
\hline \multirow{3}{*}{$\begin{array}{l}\text { Jun } \\
\text { July (Summer) } \\
\text { Aug. }\end{array}$} & 14.15 & $64.0 \pm 3.0^{\mathrm{a}}$ & $65.8 \pm 3.3^{\mathrm{a}}$ & $47.1 \pm 2.2^{\mathrm{a}}$ & $55 \pm 4.4^{\mathrm{a}}$ & $169.4 \pm 2.5^{\mathrm{a}}$ & $77.5 \pm 1.6^{\mathrm{ab}}$ \\
\hline & 13.50 & $64.3 \pm 3.5^{\mathrm{a}}$ & $65.3 \pm 3.9^{\mathrm{a}}$ & $47.1 \pm 2.6^{\mathrm{a}}$ & $40 \pm 3.7^{\mathrm{a}}$ & $163.5 \pm 1.6^{\mathrm{a}}$ & $77.5 \pm 1.7^{\mathrm{ab}}$ \\
\hline & 13.15 & $64.8 \pm 4.0^{\mathrm{a}}$ & $66.8 \pm 4.3^{\mathrm{a}}$ & $47.2 \pm 3.2^{\mathrm{a}}$ & $40 \pm 4.1^{\mathrm{a}}$ & $170.3 \pm 1.7^{\mathrm{a}}$ & $74.6 \pm 2.3^{\mathrm{ab}}$ \\
\hline \multirow{3}{*}{$\begin{array}{l}\text { Sept. } \\
\text { Oct. (Autumn) } \\
\text { Nov. }\end{array}$} & 12.30 & $66.5 \pm 5.1^{\mathrm{a}}$ & $68.9 \pm 5.3^{\mathrm{a}}$ & $50.8 \pm 3.2^{\mathrm{a}}$ & $90 \pm 5.2^{\mathrm{ab}}$ & $187.5 \pm 3.8^{\mathrm{ab}}$ & $63.4 \pm 2.6^{\mathrm{a}}$ \\
\hline & 11.30 & $71.0 \pm 3.3^{\mathrm{ab}}$ & $73.8 \pm 3.3^{\mathrm{ab}}$ & $58.0 \pm 2.2^{\mathrm{ab}}$ & $95 \pm 5.0^{\mathrm{ab}}$ & $190.5 \pm 4.6^{\mathrm{ab}}$ & $78.4 \pm 1.4^{\mathrm{ab}}$ \\
\hline & 10.15 & $78.0 \pm 3.4^{\mathrm{ab}}$ & $79.3 \pm 3.6^{\mathrm{ab}}$ & $63.0 \pm 3.5^{\mathrm{ab}}$ & $110 \pm 6.7^{\mathrm{ab}}$ & $198.8 \pm 2.8^{\mathrm{b}}$ & $86.1 \pm 5.2^{b}$ \\
\hline \multirow{3}{*}{$\begin{array}{l}\text { Dec. } \\
\text { Jan. (Winter) } \\
\text { Feb. }\end{array}$} & 10.45 & $94.8 \pm 4.3^{\mathrm{b}}$ & $95.8 \pm 4.3^{\mathrm{b}}$ & $78.0 \pm 2.1^{\mathrm{b}}$ & $182 \pm 8.0^{\mathrm{b}}$ & $200.4 \pm 4.3^{\mathrm{b}}$ & $90.3 \pm 2.1^{\mathrm{b}}$ \\
\hline & 11.0 & $96.6 \pm 5.6^{b}$ & $97.6 \pm 6.6^{b}$ & $79.6 \pm 2.4^{b}$ & $280 \pm 8.7^{b}$ & $210.1 \pm 4.8^{b c}$ & $91.4 \pm 3.1^{\mathrm{b}}$ \\
\hline & 11.45 & $93.9 \pm 5.3^{b}$ & $94.9 \pm 4.3^{b}$ & $77.2 \pm 3.6^{\mathrm{b}}$ & $265 \pm 10^{\mathrm{b}}$ & $210.4 \pm 5.1^{\mathrm{bc}}$ & $90.5 \pm 4.6^{\mathrm{b}}$ \\
\hline \multirow{3}{*}{$\begin{array}{l}\text { March } \\
\text { April (Spring) } \\
\text { May }\end{array}$} & 12.0 & $90.0 \pm 5.7^{b}$ & $90.5 \pm 5.7^{b}$ & $73.2 \pm 4.8^{b}$ & $180 \pm 9.6^{\mathrm{b}}$ & $220.6 \pm 5.2^{\mathrm{c}}$ & $90.3 \pm 2.1^{\mathrm{b}}$ \\
\hline & 12.50 & $71.2 \pm 4.3^{\mathrm{ab}}$ & $73.8 \pm 5.3^{\mathrm{ab}}$ & $67.1 \pm 4.5^{b}$ & $160 \pm 9.0^{\mathrm{b}}$ & $190.5 \pm 6.1^{\mathrm{ab}}$ & $86.4 \pm 2.5^{b}$ \\
\hline & 13.50 & $60.1 \pm 4.1^{\mathrm{ab}}$ & $61.1 \pm 4.2^{\mathrm{ab}}$ & $55.5 \pm 3.3^{\mathrm{a}}$ & $90 \pm 4.1^{\mathrm{a}}$ & $180.7 \pm 4.2^{\mathrm{ab}}$ & $81.5 \pm 1.9^{\mathrm{ab}}$ \\
\hline
\end{tabular}

- Values in mean \pm mean standard error.

- means in the same column with the same letter were not significantly different.

- $\mathrm{a}, \mathrm{b}, \mathrm{c}$ means with different superscripts were significantly different $(\mathrm{p}<0.05)$. 
Figure 1: seasonal variation in: (A) testicular weight, testicular volume and Parenchymal volume B) Leydig cells number, Tubular diameter and Epithelial height of the testicular tubule. 
Testicular weight $(\mathrm{W})$, Testicular volume and parenchymal volume $\quad(\mathrm{V})$

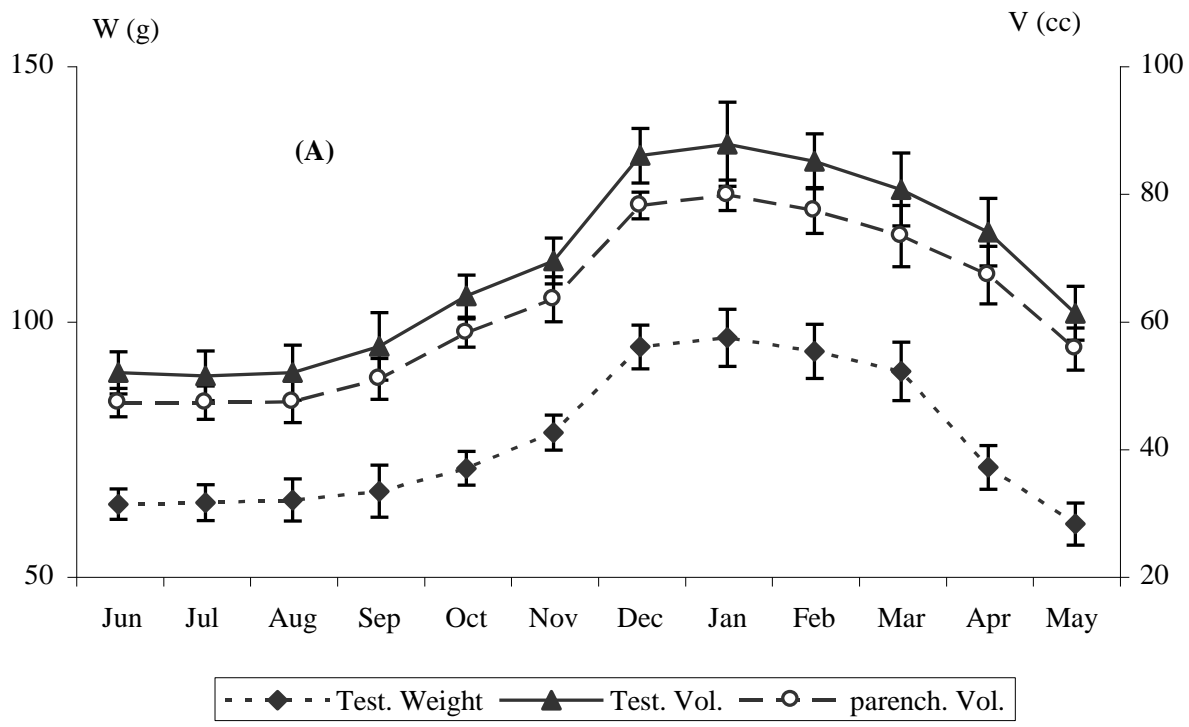

Leydig cells number (No.), diameter of semi. tub. and epith. height (um)

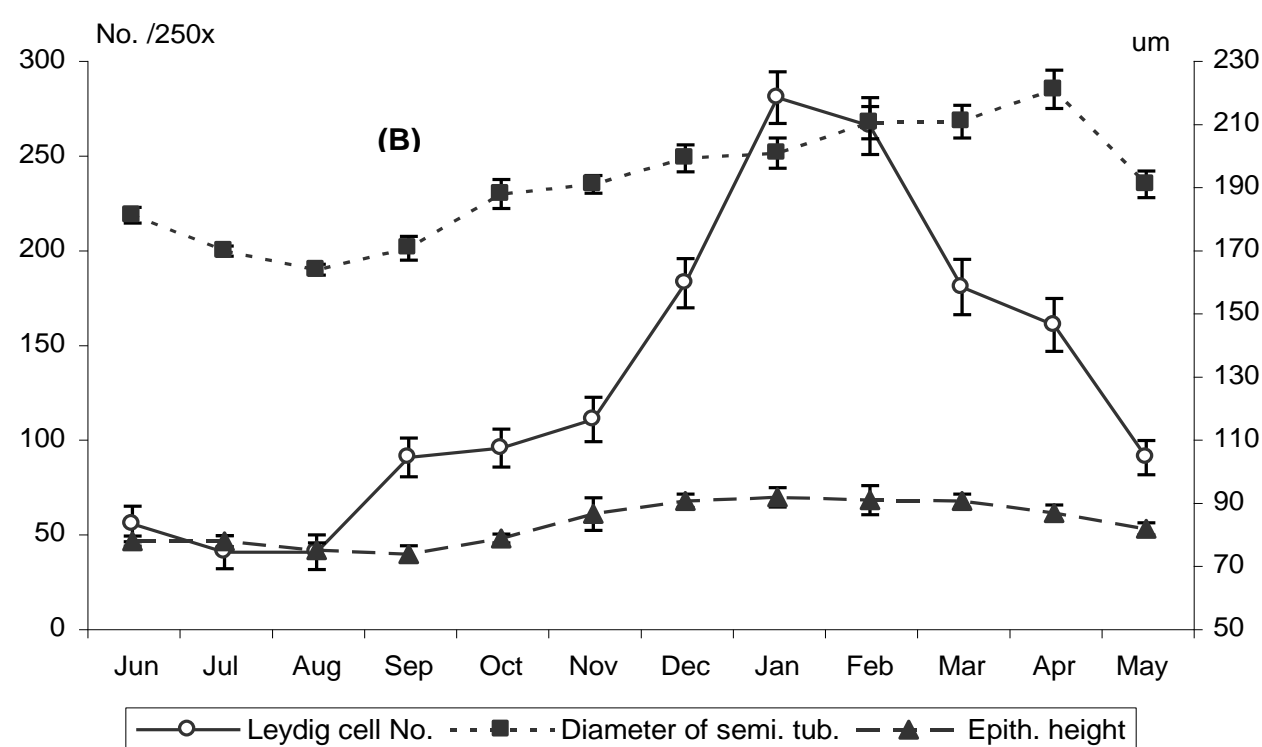




\section{3 $\beta$-HSD immunohistochemistry}

The hormonal activity of the Leydig cell was assessed by $3 \beta$-HSD enzyme immunohistochemitry. This reaction revealed dark gray granules localized in the cytoplasm of the Leydig cells. The intensity of the reaction and the population of Leydig cells showed marked annual variations. In June, July and august, a weak reaction in and low number Leydig cells were observed. September and October, intertubular tissue showed few number of Leydig cells with strong $3 \beta$-HSD reaction. The number of the Leydig cells increased to reach their maximum population and strongest $3 \beta-\mathrm{HSD}$ reaction in December, January and February (qualitative and quantitative). In March April and May, the intertubular tissues contained abundant number of Leydig cells with relatively weak $3 \beta$-HSD reaction (Figure 2).

Figure 2: Changes in $3 \beta$-HSD immunoreactivity throughout different seasons of the year in the male camel. 250x. 

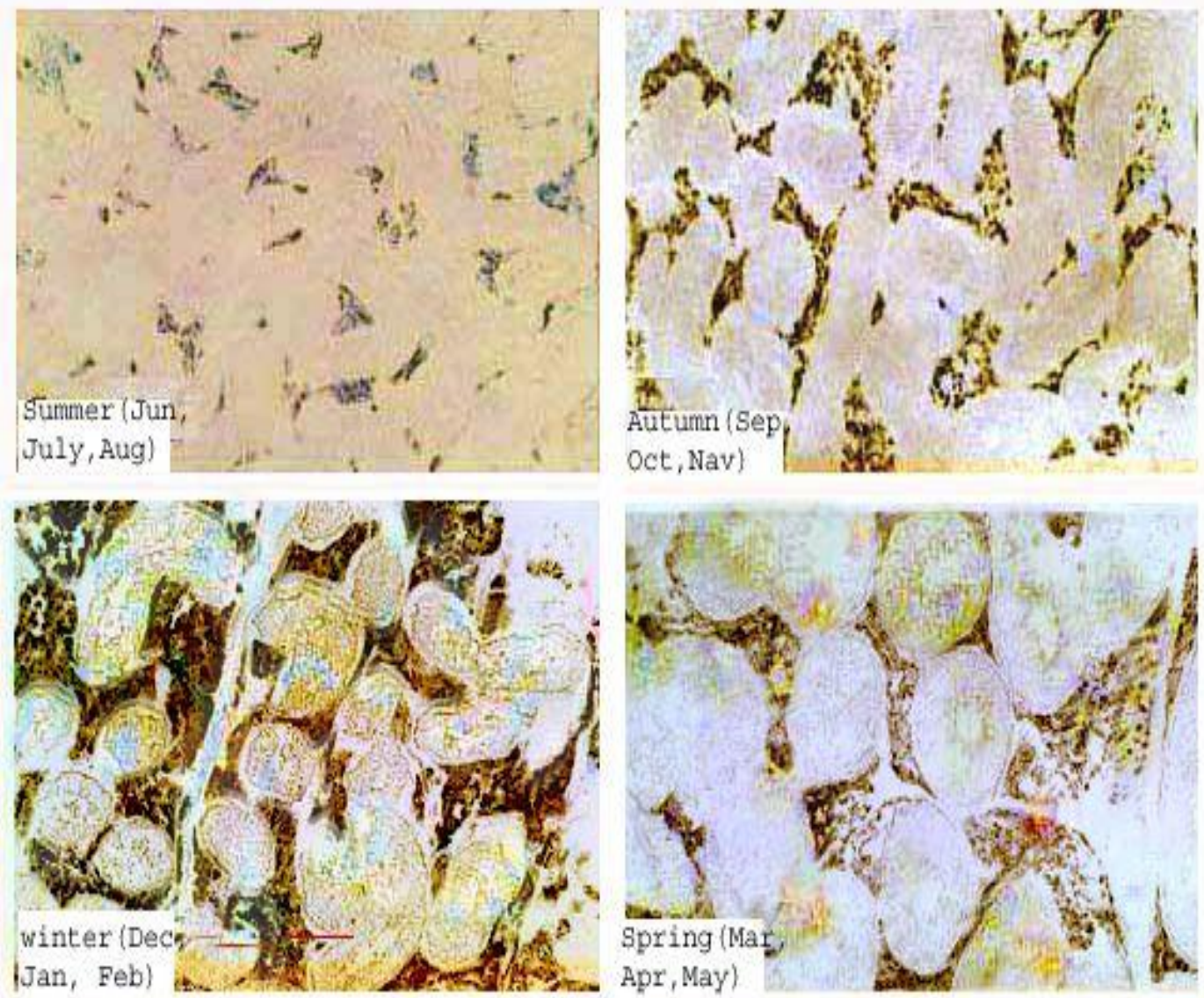


\section{Hormonal concentration}

In the beginning of the year, during January to April months, serum testosterone increased significantly and reached a peak level during these months As shown in table (2), Figure (3).

Table 2: Serum concentrations of testosterone and thyroxin all over the year in male camels $(n=6)$.

\begin{tabular}{|c|c|c|c|}
\hline Month & Season & Testosterone $\mathrm{ng} / \mathrm{ml}$ & Thyroxin ng/dL \\
\hline June & \multirow{3}{*}{ Summer } & $2.58 \pm 0.72^{c}$ & $66.50 \pm 7.81^{\mathrm{bc}}$ \\
\hline July & & $1.30 \pm 0.75^{\mathrm{c}}$ & $52.16 \pm 9.05^{\mathrm{c}}$ \\
\hline August & & $1.11 \pm 0.56^{\mathrm{c}}$ & $50.33 \pm 7.70^{c}$ \\
\hline September & \multirow{3}{*}{ Autumn } & $2.54 \pm 0.44^{\mathrm{c}}$ & $41.33 \pm 16.06^{\mathrm{c}}$ \\
\hline October & & $1.43 \pm 0.26^{\mathrm{c}}$ & $4.42 \pm 4.49^{\mathrm{cd}}$ \\
\hline November & & $1.49 \pm 0.40^{\mathrm{c}}$ & $26.50 \pm 2.57^{\mathrm{d}}$ \\
\hline December & \multirow{3}{*}{ Winter } & $15.94 \pm 3.40^{\mathrm{b}}$ & $64.50 \pm 8.34^{\mathrm{bc}}$ \\
\hline January & & $30.86 \pm 2.96^{\mathrm{a}}$ & $75.83 \pm 12.08^{b}$ \\
\hline February & & $30.37 \pm 3.00^{\mathrm{a}}$ & $96.50 \pm 19.20^{\mathrm{ab}}$ \\
\hline March & \multirow{3}{*}{ Spring } & $29.93 \pm 3.88^{\mathrm{a}}$ & $91.00 \pm 17.39^{\mathrm{b}}$ \\
\hline April & & $30.99 \pm 5.88^{\mathrm{a}}$ & $116.00 \pm 18.50^{\mathrm{a}}$ \\
\hline May & & $13.59 \pm 2.23^{b}$ & $87.83 \pm 6.16^{\mathrm{b}}$ \\
\hline
\end{tabular}

- Values in mean \pm mean standard error.

- Means in the same column with the same letter were not significantly different.

- $a, b, c$ means with different superscripts were significantly different $(p<0.05)$.

Figure 3: annual variation in serum testosterone and thyroxin levels in the male dromedary.

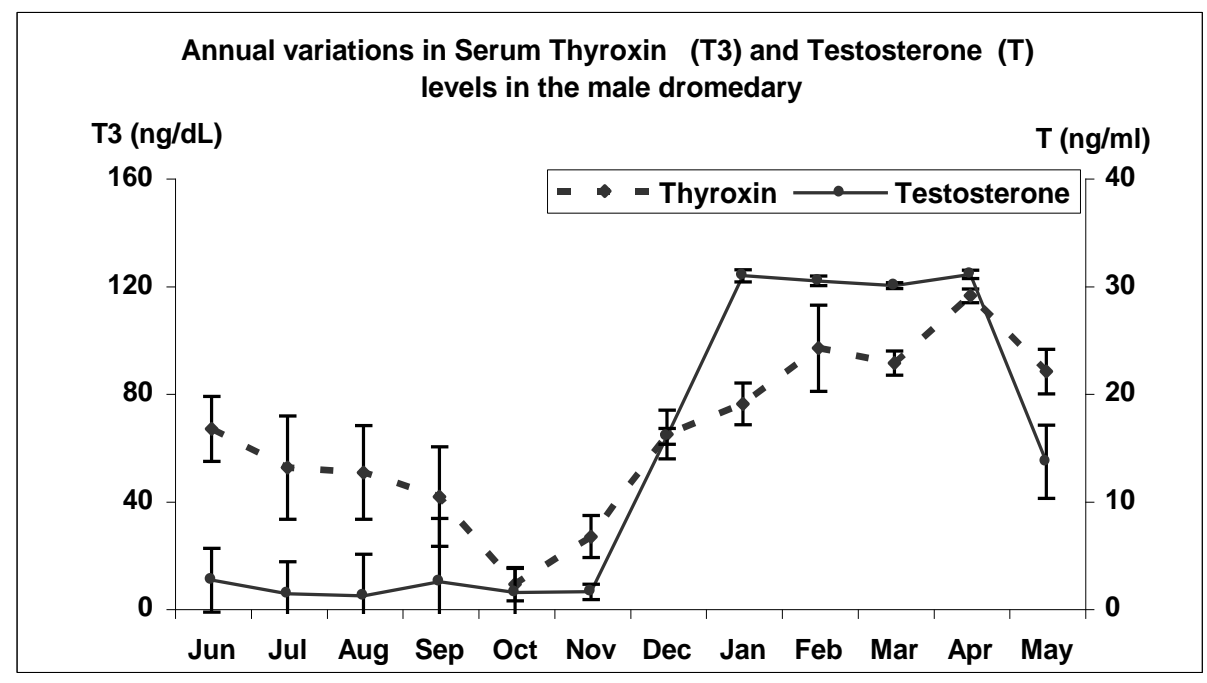




\section{DISCUSSION}

The reproductive activity of the camel builds up during September and October, and the animal is in actual rut during November, December, January and February, with a drop in March and thereafter (Abdel-Raouf and owaida, 1974, Abdel-Raouf et al., 1975 and Tingari et al, 1984). In the present study, the testes began to increase in volume from quiescence (September) and attained a peak during breeding season (December, January and February). Then, testes declined in volume in March and April to reach the lowest values in July. The present findings are coincident with those of Singh and Bharadwaj (1978) and Zayed et al. (1995).

Thornton et al. (2002) suggested that plasma androgen and/or IGF-1 levels may be important in modulating the expression of some $\mathrm{s}$ in the regulation of the testosterone production in Leydig cells. In this study, a steroidogenic enzymes like 3 beta-HSD. These results suggest that 3 beta HSD is a key enzyme strong positive relation between serum androgen and histochemistry reaction of $3 \beta$-HSD was noticed. In June and July, The Leydig cells showed low population and a very weak $3 \beta$ HSD activity. The activity of the $3 \beta$-HSD increased steadily in September and October and reached the maximum activity in December, January, February and March (qualitative and quantitative). The Leydig cells are in highest population and highest morphological differentiation and their smooth ER (SER) is highly developed (Zayed et al. 1995). In April and May, the Leydig cells decreased steadily in population and $3 \beta$ HSD activity to reach the minimum state in Jun and July. The cells were small in size, SER is reduced and many Leydig cells are degenerating (Zayed et al. 1995). These findings supported the previous results reported for camel (Yagil and Etzion, 1980), stallion (Johnson and Thompson, 1987) and Japanese black bear (Komatsu et al 1997).

Serum testosterone level was $15.94 \pm 3.40 \mathrm{ng} / \mathrm{ml}$ in December, reached a plateau in April $(30.99 \pm 5.88 \mathrm{ng} / \mathrm{ml})$ and decreased to $13.59 \pm$ $2.23 \mathrm{ng} / \mathrm{ml}$ in May and dropped to its lowest level at June $(2.58 \pm 0.72$ $\mathrm{ng} / \mathrm{ml}$ ) and continued at this nadir through the summer and autumn seasons. It has been previously shown that the differential testosterone synthesis between the seasons in the dromedary is not quantitative. However, during the mating season, the synthesis of testosterone synthesis is through both 4-ene and 5-ene pathways, whereas during the non mating season, the synthesis occurs mainly through the 5-ene pathway and at a lower rate than that of this pathway during the mating 
season (Bedrak et. al., 1983). Delgadillo et al. (2004) reported that Short days enhanced testosterone secretion and long days inhibited it in seasonal breeder males. During the mating season, Leydig cells were highly packed and larger than during the nonmating season (Friedlander et. al., 1984).

Abdel-Raouf et al (1975) claimed that the largest seminiferous tubule diameters and the greatest numbers of spermatogonia, spermatids and spermatozoa were found in the spring. The numbers of mature Leydig cells, compared to the numbers of pre-Leydig and immature Leydig cells, increased by the end of winter so that, during the spring, the interstitial cells were mainly of the mature type. Degenerative changes with diminished numbers of mature cells were seen in the summer and this trend continued into early and mid-autumn. In the stallion (long day breeder), Johnson and Thompson (1987) found that the volume of Smooth Endoplasmic Reticulum (SER)/g and testosterone/g tended to be higher in the breeding than non-breeding season. Leydig cell number/g, volume of SER/testis, testosterone/testis, and Leydig cell number/testis were significantly greater in the breeding than in the non-breeding season. Volume of SER/testis and testosterone/testis were related significantly to the cell number/testis, and SER/testis was related $(\mathrm{P}<0.05)$ to testosterone/testis.

Our findings support the concept that the thyroid gland plays a fundamental role in seasonal reproduction in the male camel. An annual cycle of serum thyroxin was detected; values reached a peak in winter (late breeding season) and a minimal level in summer (late anestrus). Significant increase in serum thyroxin concentration was found during the period from December till June. Maximum level of thyroxin was found in April $(116.00 \pm 18.5 \mathrm{ng} / \mathrm{dL})$. The increase in serum thyroxin concentrations was coincident with an increase in serum androgen concentration. Moreover, a simultaneous significant decline in serum thyroxin and androgen levels were found nearly in the same time during the nonmating season. Wasfi, et al. (1987) reported values of $9.33 \pm 1.15$ $\mathrm{ng} / \mathrm{ml}(1.43 \pm 0.18 \mathrm{nmol} / \mathrm{l})$ for $\mathrm{T}_{3}$ concentration in normal Saudi Arabian camels. Nazifi et al., (1999) found that the concentrations of T3 and T4 were higher in the breeding season compared with the rest of the year $(p<0.05)$. Thyroidal hormones (T3 and T4) showed significant correlations with serum total protein and glucose.

A significant positive correlation between plasma levels of cholesterol and both serum thyroxin and testosterone in males was reported (Heller et. al 1981). Webster et al (1991), Anderson et al. 
(2003) and Hernandez et al (2003) mentioned that thyroid hormones did not alter onset of the breeding season but they were permissive for various species to enter seasonal anestrus. Responsiveness to $T_{4}$ is lost gradually during the mid to late anestrous season and thyroid hormones can influence the timing of the breeding season and thus may be required for the maintenance or entrainment of the endogenous reproductive rhythm (Anderson et al, 2002 Billings et al, 2002). Viguié et al (1999) provided strong evidence that thyroid hormones can act directly within the brain to promote seasonal inhibition of neuroendocrine reproductive function in the ewe. Further, the reproductive neuroendocrine axis is not equally responsive to thyroid hormone at all times of the year (Thrun et $a l$, 1997). It is concluded that the decline of thyroid function, as gauged by hormone secretion in summer, aids in preservation of body water by decreasing pulmonary water loss and dropping basic metabolism (Yagil et al, 1978).

Form the present findings, it seems that, Thyroid hormones are necessary only during a limited interval early in the breeding season to promote seasonal reproductive activation in the male dromedary. There is a critical period of responsiveness during which thyroid hormones must be present for rut to develop. In conclusion, the present findings indicated that there is a concomitant rise and fall in $3 \beta-\mathrm{HSD}$, serum testosterone and thyroxin level in the male dromedary which is indicative and diagnostic for the onset of reproductive seasonality. Thyroxin is a key hormone for the resumption of sexual activity after the non rut period in the dromedary.

\section{REFERENCES}

Abdel-Raouf, M. and Owaida, M.M. (1974): Studies on reproduction in camels (Camelus dromedarius). IV. Gross changes in the morphology of the testis in relation to age and season. Ass. Vet. Med. J., 1 :215-223.

Abdel-Raouf, M.; Fateh El-Bab, M.R. and Owaida, M.M. (1975): Studies on reproduction in the camel (Camelus dromedarius). V. Morphology of the testis in relation to age and season. $\mathrm{J}$ Reprod. Fertil. 43: 109-116.

Anderson, G.M.; Connors, J.M.; Hardy, S.L.; Valent, M. and Goodman, R.L. (2002) Thyroid hormones mediate steroid-independent seasonal changes in Luteinizing Hormone pulsatility in the ewe. Biol. Reprod. 66, 701-706. 
Anderson, G.M.; Hardy, S.L.; Valent, M.; Billings, H.J.; Connors, J.M. and Goodman, R.L. (2003): Evidence that thyroid hormones act in the ventromedial preoptic area and the premammillary region of the brain to allow the termination of the breeding season in the ewe. Endocrinol. 144, 2892-2901.

Bedrak, E.; Rosenstrauch, A.; Kafka, M. and Friedlander, M. (1983): Testicular steroidogenesis in the camel (Camelus dromedarius) during the mating and the nonmating seasons. Gen. Comp. Endocrinol. 52, 255-64.

Billings, H.J.; Viguié, C.; Karsch, F.J.; Goodman, R.L.; Connors, J.M. and Anderson, G.M. (2002): Temporal requirements of thyroid hormones for seasonal changes in LH secretion. Endocrinol., 143, 2618-2625.

Conley, AJ and Bird, IM (1997): The role of cytochrome P450 17 alphahydroxylose and 3 beta-hydroxysteroid dehydrogenase in the integration of gonadal and adrenal steroidogenesis via the delta 5 and delta 4 pathways of steridogenesis in mammals. Biol. Reprod 56:789-799.

Delgadillo, J.A.; Cortez, M.E.; Duarte, G.; Chemineau, P. and Malpaux, $B$. (2004): Evidence that the photoperiod controls the annual changes in testosterone secretion, testicular and body weight in subtropical male goats. Reprod. Nutr. Dev. 44: 183-193.

Ferre, F.; Breuiller, M.; Cedarol, L.; Duchesne, MJ.; Saintot, M.; Descomps, B. and Crustes de Paulet, A. (1975): Human placental D5-3 $\beta$ hydroxysteroid dehydrogenase activity D5$3 \beta \_$HSD; intracelluler distribution, kinetic properties, retrainhibition and influence of membrane delipidation. Steroids 26:551-570.

Friedlander, M.; Rosenstrauch, A. and Bedrak, E. (1984): Leydig cell differentiation during the reproductive cycle of the seasonal breeder Camelus dromedarius: An ultrastructural analysis. Gen. Comp. Endocrinol., 55, 1-11.

Guyton, A.C. (1991): The thyroid metabolic hormones in: Textbook of medical physiology, $8^{\text {th }}$ edn: W.B. Saunders Company, Philadelphia.

Heller, R.F.; Miller, N.E.; Lewis, B.; Vermeulen, A.; Fairney, A.; James, V.H. and Swan, A.V. (1981): Associations between sex hormones, thyroid hormones and lipoproteins Clin. Sci.61 (5) 649-51. 
Hernandez, J.A.; Hallford, D.M. and Wells, N.H. (2003): Ovarian cyclicity in thyroid-suppressed ewes treated with propylthiouracil immediately before onset of seasonal anestrus. J. Anim. Sci. 81:29-34.

Johnson, L. and Thompson, D.L. Jr. (1987): Effect of seasonal changes in Leydig cell number on the volume of smooth endoplasmic reticulum in Leydig cells and intratesticular testosterone content in stallions. J. Reprod. Fertil. 81, 227-32.

Komatsu, T.; Tsubota, T.; Yamamoto, Y.; Atoji, Y. and Suzuki, Y. (1997): Seasonal changes in the immunolocalization of steroidogenic enzymes in the testes of the Japanese black bear (Ursus thibetanus japonicus). J. Vet. Med. Sci. 59, 521-529.

Lacoste, D; Bélanger, A. and Labrie, F. (1990): Biosynthesis and degradation of androgen in human prostatic cancer cell lines. In: Castagretta L, D'Aquino S, Labrie F, Bradlow H (eds) Steroid formation, degredation and action in peripheral tissues. Ann N Y Acad Sci. 595:389-392.

Nazifi, S.; Gheisari, H.R. and Poorabbas, H. (1999): The influences of thermal stress on serum biochemical parameters of dromedary camels and their correlation with thyroid activity. Comp. Clinic. Pathol. 9, 49-54.

Penning, TM. (1997): Molecular endocrinology of hydroxysteroid dehydrogenases. Endocr Rev. 18:281-305.

Racey, P.A. (1978): Seasonal changes in testosterone levels and androgen-dependent organs in male moles (Talpa europea). J. Reprod. Fert. 52, 195-200.

SAS. (1995): Statistical Analysis System. SAS/ STAT Users's Guide, Release 6.12 Edition. Cary, NC. SAS inst., Inc.

Scherle, W.E. (1970): A simple mehod for volumetry of organs in quantitative stereology Mikroskopie. 26: 57-60.

Simard, J.; Couet, J.; Durocher, F.; Labrie, Y.; Sanchez, R.; Breton, N.; Turgeon, C. and Labrie, F. (1993): Structure and tissuespecific expression of a novel member of the rat 3 betahydroxysteroid dehydrogenase/delta5-delta 4 isomerase (3 beta-HSD) family. The exclusive 3 beta-HSD gene expression in the skin. J. Biol. Chem. 268:19659-19668. 
Simard, J.; Sanchez, R.; Durocher, F.; Rheaume, E.; Turgeon, C.; Labrie, Y.; Luu-The, V.; Mebark, F.; Morel, Y. and De Launoit, $Y$. (1995): Structure-function relationship and molecular genetics of the 3 beta-hydroxysteroid dehydrogenase gene family. J. Steroid Biochem Mol Biol 55:489-505.

Singh, U.B. and Bharadwaj, M.B (1978): Histological and histochemical studies on the testis of camel (Camelus dromedarius) during the various seasons and ages. Part II, Acta Anat. 101, 280-288.

Thornton, M.J.; El-Alfy, M. and Labrie, F. (2002): Seasonal changes in the expression of some steroidogenic enzymes in male red deer skin. Endocrine (Abstract) 4, 90.

Thrun, L.A.; Dahl, G.E.; Evans, N.P. and Karsch, F.J. (1997): A Critical period for thyroid hormone action on seasonal changes in reproductive neuroendocrine function in the ewe. Endocrinol. 138, 3402-3409.

Tingari, M.D.; Ramos, A.S.; Gaili, E.S.; Rahma, B.A. and Saad, A.H. (1984): Morphology of the testis of the one-humped camel in relation to reproductive activity. J. Anat. 139, 133-43.

Vaughan, M.K.; Powanda, M.C.; Richardson, B.A.; King, T.S.; Johnson, L.Y. and Reiter, R.J. (1982): Chronic exposure to short photoperiod inhibits free thyroxin index and plasma levels of TSH, T4, triiodothyronine (T3) and cholesterol in female Syrian hamsters. Comp. Biochem. Physiol. A. 71, 615-8.

Viguié, C.; Battaglia, D.F.; Krasa, H.B.; Thrun, L.A. and Karsch, F.J. (1999): Thyroid hormones act primarily within the brain to promote the seasonal inhibition of Luteinizing Hormone secretion in the ewe. Endocrinol. 140, 1111-1117.

Wasfi, I.A.; Hafez, A.M.; El-Tayeb, F.A.A. and El-Taher, A.Y. (1987): Thyroid hormones, cholesterol and triglycerides level in the camel. Res. Vet. Sci. 42, 418.

Webster, J.R.; Moenter, S.M.; Woodfill, C.J. and Karsch, F.J. (1991): Role of the thyroid gland in seasonal reproduction. II. Thyroxine allows a season-specific suppression of gonadotropin secretion in sheep. Endocrinol. 129, 176-183.

Willett, E.L. and Ohms, J.L. (1957): Measurement of testicular size and its relation to production of spermatozoa by bulls. J. Dairy Sci. 12: $1559-1569$.

Wilson, J.G. (1975): Hypothyroidism in ruminants with special reference to fetal goiter. Vet. Rec. 97, 161-164. 
WrobeL, K.H. (1990): The postnatal development of the bovine Leydig cell population. Reprod. Dom. Anim. 25, $51-60$.

Yagil, R. and Etzion, Z. (1980): Hormonal and behavioural patterns in the male camels (Camelus dromedarius). J Reprod Fert, 58, 6165 .

Yagil, R.; Etzion,, Z. and Ganani, J. (1978): Camel thyroid metabolism: effect of season and dehydration. J. Appl. Physiol. 45, 540-4.

Zayed, A.E.; Hifny, A.; Abou-Elmagd, A. and Wrobel, K.H. (1995): Seasonal changes in the intertubular tissue of the camel testis (Camelus dromedarius). Ann. Anat.,177:199-212. 